\title{
Publication Activity as an Indicator of Contribution of Flagship University to Regional Development
}

\author{
Olga E. Vanyushkina 1[ORCID 0000-0003-1353-1356], \\ Maria N. Ugryumova ${ }^{1 *[O R C I D ~ 0000-0003-3833-3866], ~}$ \\ Anna V. Mukhacheva 1[ORCID 0000-0002-3720-4969]
}

\author{
${ }^{1}$ Yaroslav-the-Wise Novgorod State University, Veliky Novgorod, Russia \\ trofimova_maria@list.ru
}

\begin{abstract}
The article is devoted to the analysis of publication activity of the flagship university (scientometric indicators of teachers and researchers) as one of the key indicators for assessing the contribution of the flagship university to the social and economic development of the region. While solving the research tasks, the authors defined the list of scientometric indicators for assessing scientific results, analyzed the scientometric indicators of development of Yaroslav-the-Wise Novgorod State University (Veliky Novgorod) for the past three years, determined the importance of a further increase in publication activity of the university for a positive influence on the regional development. The authors consider the strategy for transformation and integration of the flagship university into the University-Region ecosystem of the regional innovative development fixed at federal and regional levels, in order to introduce advanced and knowledge-intensive technologies into the digital economy of the territory. The authors described the first results obtained within the indicated collaboration and the performance of the university as an autonomous strategic agent of regional transformations. The authors outlined the main directions of innovative development of Yaroslav-the-Wise Novgorod State University and the Novgorod Region as an advanced scientific and technological center (in the field of intelligent electronics among others), the center for developing social, anthropologic, cultural, urban and other studies which determine current and future directions of the university's publication activity. The authors note an increase in scale and effectiveness of research due to the interaction between the region and the flagship university, which manifests itself both in the growth of publication activity and in an increased volume of attracted grant funds which, in turn, are the source of financing scientific publications. The number of publications co-authored with residents of other states and industrial partners increased. To obtain results, the authors used a comparative method (quantitative and qualitative analysis), modern tools for bibliometric analysis, forecasting, an economic and statistic method.
\end{abstract}

Keywords: innovative development of university, science intense technologies, scientometric indicators, publication activity, regional economics

\section{INTRODUCTION}

In many regions of Russia, there is an interrelation between the development of higher education system and territorial socioeconomic indicators which, as a rule, is of significant direct nature.

One of such territories is the Novgorod Region where the strategy for the development of the regional center (Veliky Novgorod) as a university town is officially adopted and a special attention is paid to the educational potential of the territory as a key priority and support for the social and economic development.

Large federal scientific and education projects are being implemented: the construction of Novgorod Technical School and the Intelligent Electronics - Valdai innovative scientific and technical center. According to the results of the Archipelago 2121 accelerator, Yaroslav-the-Wise Novgorod State University (the flagship university of the Novgorod Region) (hereinafter - NovSU) was 
recognized as a the best university for training personnel for the digital economy as well as an only pilot region for introducing innovations.

In the era of digitalization there arises an interdependence of the models of digital region and digital university. Frequently, it is the developments of a flagship university as a center for the newest advanced technologies and for the practice of their application that ensure the digital development of the territory, the introduction of digital technologies and services to create the support system for making decisions at the federal and municipal levels [1].

According to the definition given by the World Bank, the digital economy is a system of economic, social and cultural relations based on the use of information and communication technologies [2]. To some extent, digitalization covers all economic sectors, and this trend is increasing. According to HSE ISSEK calculations, the contribution of digitalization to GDP of Russia will increase from $1 \%$ in 2017 to $18.4 \%$ by 2030 , and the contribution of information industry will increase from $0.1 \%$ to $2.3 \%$ over the same period [3].

In regions, the development of knowledgeintensive digital technologies should be based on industries specific for the given region. "As a factor in economic growth, innovations are especially important for those Russian regions which possess a sufficiently high industrial and intellectual potential. However, the territorial development is associated with both the use of achievements of scientific and technical progress, advanced technologies and certain opportunities for their independent creation and implementation" [4]. In fact, the innovative economy is based on knowledge-intensive technologies. Knowledge is a key aspect of the innovative economy. "Systemic relationship between the development of innovative education and the development of innovative economy can be traced not only in the structure of the world economy; it turns out this model is also working at the regional level..." [5]. The regional flagship university becomes the center for generation of innovative activity, formation of patents and developments, provides for the development of fields of the digital economy of the territory, the growth of social and economic indicators of the region.

So, economic development of a region is possible provided there is a significant contribution of regional universities to the development of economy. The university's contribution can manifest itself in three areas: project initiator, partner and source of human and analytical resources [6]. The function of the higher school has always been to prepare high quality personnel, especially demanded in the region, to develop and introduce new technologies [7]. As a rule, scientific advanced hightech productions and associations has always gravitated towards the university as a center that unites intellectual resources. "From this point of view, it seems logical to consider the activities of universities in the context of the analysis of network alliances created to produce highly intellegent results" [8].

Launching the program of strategic academic leadership of universities, the need to systemically unite and agree the R\&D strategy in the Russian Federation, the Science and Universities national project, the Integration, Research Leadership, Personnel, Infrastructure federal projects to implement the research technological breakthrough determine the relevance of searching for models and formats for effective collaboration between national flagship universities and regional authorities [9].

The analysis of researches testifies that a significant part of regional higher education systems in the Russian Federation does not completely realize their potential for regional development [10]. Similarly, regional development has undiscovered reserves for realizing positive effects for flagship universities' activities. The Strategic Academic Leadership Program (PSAL) based on the idea of providing for the goals of national development and supporting for universities ready to collaborate with regional authorities for further development is intended to correct this situation.

Developing the regional economy, it is relevant to increase the third role and responsibility of flagship universities for the regional development, which determines their place in the UniversityRegion ecosystem. This is especially true for universities which, until recently, practically did not manifest themselves in the regional development, were not included in a functioning and effective ecosystem. The situation is changing rapidly. Thus, back in 2017, according to the results of an analysis of 79 universities, NovSU was assigned to a group with a low impact level (all sub-indices were below the average) [11]. Three years of active innovative transformations at the university ensured a certain contribution to the regional development, primarily due to the implementation of a large number of innovative projects [12].

In the assessment of the contribution of a Russian university to the regional innovative 
development, one of the significant indicators is the indicator of quantity and quality of scientific works of university employees in the leading international scientometric data bases Web of Science and Scopus, which determines the relevance of our article. According to certain studies, this indicator is not quite objective, since in Russia there are few scientific journals presented in the above data bases, which fact " ... creates barriers to the growth of the number of publications" [13]. But in international practice, it is the scientometric indicators of Web of Science and Scopus that are recognized as relevant for assessing the research potential of a university. It was proved that in the modern world, it is the results of intellectual activities that are the main tool for the development of economic entities [14], which facts explains the relevance of our research.

The reverse statement is also true: given the existence of the University-Region ecosystem based on the development of knowledge-intensive technologies which are optimal for a given economic entity, the development of scientific sector of the economy primarily based on university platforms is inevitable. Consequently, we can assume that the actions aimed at implementing the regional Development Strategy in the innovative way and transforming knowledge-intensive technologies into real tools for the university and regional development will turned out to be necessary and relevant and will be introduced at all levels in the University-Region ecosystem, which is one of four priority vectors of the development of the Novgorod Region specified in the Development Strategy. By 2025, the functioning of the Region-University ecosystem is being planned, which “...provides for solving the task of advanced training of high-quality specialists in the interests of social and economic development of the region" [15], thanks to a number of projects being implemented.

The scientific novelty of the research is due to the fact that a qualitative increase in scientometric indicators of the university is assessed in terms of expanding the collaboration between the university and industrial enterprises. A review of studies showed that scientometric indicators as an important criterion for evaluating the activities of the university in the context of the development of the regional economy have not been previously considered.

\section{MATERIALS AND METHODS}

The purpose of this research is to analyze the scientometric indicators of the university's employees as one of the main criteria for assessing the contribution of the university to the development of the regional economy.

To achieve this purpose, it is necessary to solve the following tasks:

1) determine the main scientometric indicators for assessing scientific activities;

2) analyze the university performance for 2018 2020 in terms of their impact on the region's development;

3) determine the further direction or need to correct the publication activity of the university in order to positively influence the regional development.

To obtain definite research results, we use a comparative method, modern methods of bibliometric analysis, and a forecasting method. Qualitative research methods will allow us to define the main trends in the region's development and to trace their connection with achievements in corresponding scientific areas.

The analysis of quantitative indicators will allow us to reveal the dynamics and main trends in the development of scientometric indicators of teaching staff, their impact on the activities of the flagship university and the social and economic development of the region, and carry out the predicative analytics of possible future states of these indicators, determine methods for achieving their desired level.

\section{RESULTS}

The main indicator in evaluating scientific activity is the number of publications, including the type of publications (Conference Paper is traditionally valued lower than Article and Review). One can also consider the dynamics of changes in publication activity in certain areas, the most significant for the development of the region. Thus, the focus of the key scientific regional projects of the Novgorod Region on innovative and technological development and the projects declared in the Priority 20.30 program determine the key strategic direction for the development of the university's publication activity (smart electronics, the development of cultural identity).

The factors that make up the innovative development of the region can be represented as a diagram that reflects the main vectors of development (Figure 1).

Practically all of the listed factors of the region's 
innovative development are based in some degree on the achievements of the region's scientists, and scientific and technological, educational factors are almost completely ensured by the university activities. Traditionally, university rankings, as well as the evaluation of scientific contributions, include the number of indicators, among them there is a presence of a person being evaluated in international bases of scientific citation. It is these indicators that significantly influence the promotion of a university in various programs, financing and realization of large-scale scientific and technological innovative projects as a part of various consortia. This, in turn, ensures the further comprehensive development of all project participants.

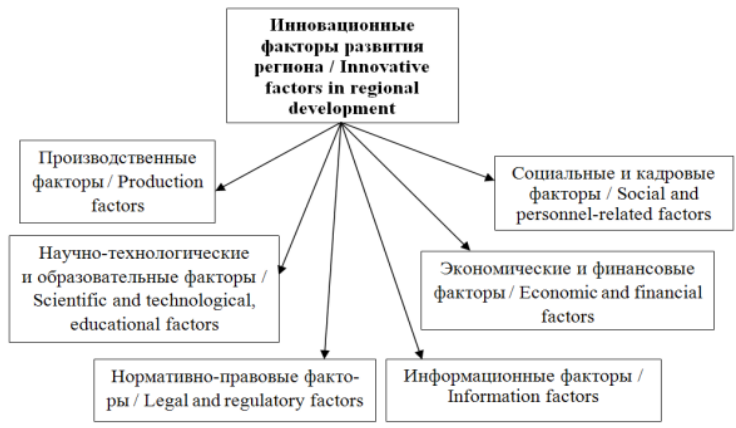

Figure 1. Innovative factors in the development of a region

Source: [4]

Indicators of Scopus and Web of Science show the development of NovSU publication activity in 2018-2020, the period of active innovative transformations both at the university and in the region as a whole (Figure 2).

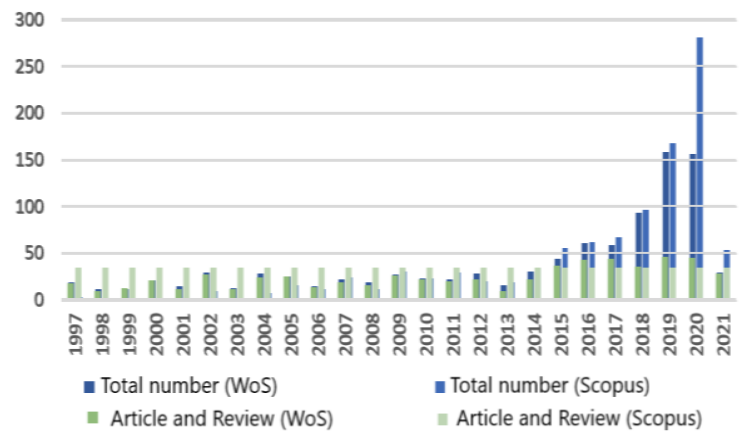

Figure 2. Comparison of the total number of publications and the type "Article" and "Review", NovSU

Source: Compiled by the authors

It may seem that there is a quantitative growth only. No doubt, Conference Paper is important for the development of the scientist, the university, the region as a whole. In particular, it is thanks to such events as international scientific and practical conferences that partnerships between university scientists and representatives of industrial enterprises are expanding. But of special importance for the evaluation of scientific results are Article and Review (for the growth dynamics see Figure 3).

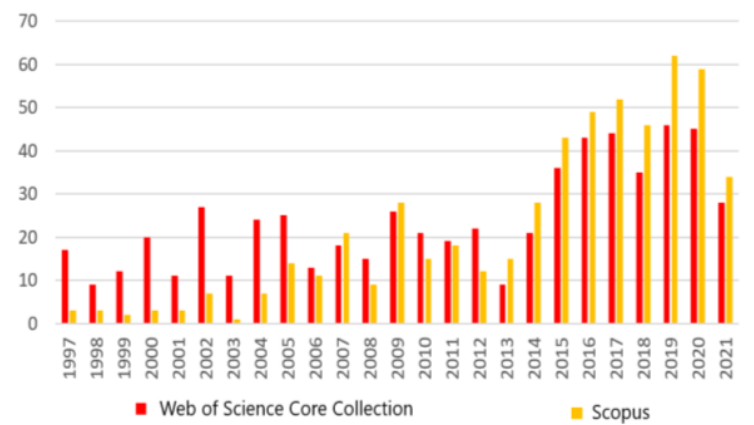

Figure 3. Number of publications by NovSU authors, referred to Article and Review types Source: Compiled by the authors

At last, the third indicator of interest to us is research funding. Pay attention that in this case, we will analyze a five-year indicator plus a current year (2021). A number of reasons serve as a basis for such a limitation: existing restrictions on the volume and period of the array of data being analyzed on scopus.com and webofscience.com platforms; economic changes influencing the scientific sector funding; finally, a time period in 5 years standard for the whole world (including the scientometric systems under consideration) which is adopted in the scientific community as a period that fairly objectively reflects the current state of research activities in universities.

As a result of the analysis, we obtained the following data:

- Scopus: for the period from 2016 to October 2021 , out of 733 scientific papers of all types indexed in the database, funding organizations were identified in 233 articles;

- Web of Science Core Collection: for the period from 2016 to October 2021, out of 560 scientific papers of all types indexed in the database, funding organizations were identified in 227 articles.

The distribution of articles by years is shown in the graph (Figure 4).

The growth of international collaboration of research authors is the evidence of the development of scientific relations, as well as future industrial and economic ones (Figure 5). 


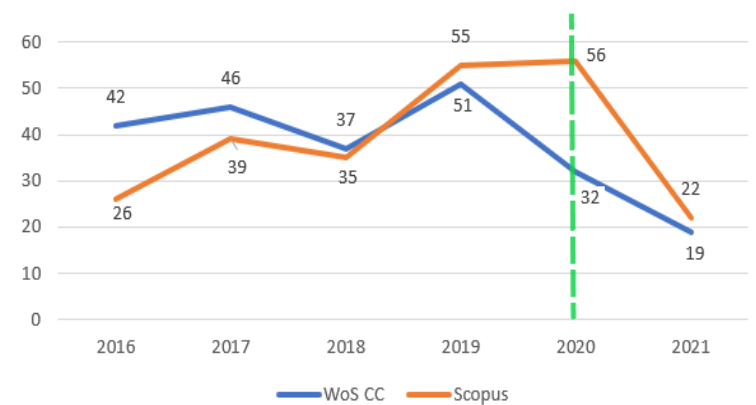

Figure 4. Publications that have a source of funding Source: Compiled by the authors

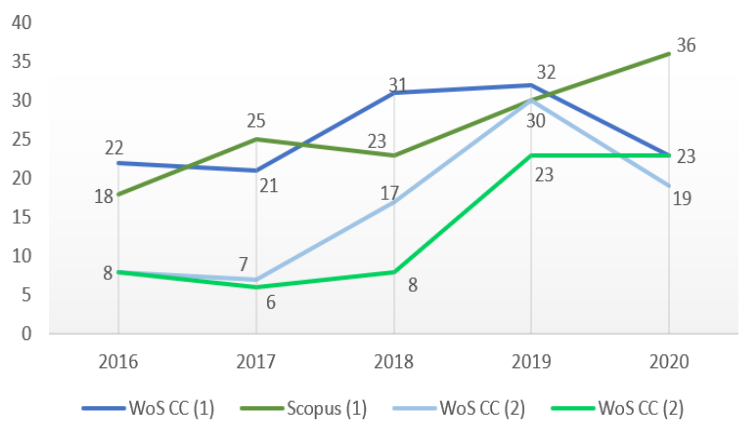

Figure 5. Total number of publications with an international team of authors (1); publications with co-authors from partner organizations (except educational and scientific ones) (2)

Source: Compiled by the authors

On this graph, there are only 2016-2020, and it is obvious that by 2020 the indicators will increase, since the process of indexing some publications is quite long (which also influenced the results in Figure 4). But according to the available data, it is clear that, in general, international scientific relations are developing. Good dynamics is also observed in the number of co-authors, referred not to educational institutions, but to enterprises, firms, industrial concerns, etc. Among such partner organizations (mainly manufacturing enterprises) are, for example, PJSC Tupolev, SINTERFACE Technologies, Olimex Ltd, OKB-Planeta PLC, CONNECTOR OPT LLC, OOO OPTIMIKST LTD, NovBiotech LLC and others. Such connections ensure the introduction of new technologies into the production process and, in the long term, a certain economic result not only for the university, but also for the region as a whole.

\section{DISCUSSION}

The presented results theoretically confirm the importance of publication activity indicators for assessing the scientific potential and development of the flagship university and the socio-economic development of the region, in practice, they indicate a significant increase in NovSU scientometric indicators since 2018. In general, it can be stated that the growth of scientometric indicators is an important indicator of the real state of affairs in the field of scientific analysis and research, serving as a "locomotive" for the innovative development of scientific and educational organizations and branches of the digital economy of the region, which, nevertheless, should be supplemented with other indicators (volume and focus of received grants, contractual work with government officials and employers, etc.).

Evaluation of scientific achievements on the basis of scientometric criteria of world standards will also make it possible to draw a correct conclusion about the intermediate stages of the regional development strategy, adopted for a differentiated time perspective $(5,10,15$ years $)$.

Further study of not only quantitative, but also qualitative characteristics of the publication activity of the teaching staff of the flagship university is also required. This problem has been partly solved through the number of funded publications and publications in co-authorship with industry partners.

\section{CONCLUSION}

Analysis of the publication activity of the teaching staff and researchers of the university is one of the indicators for evaluating the effectiveness of the scientific activities of the flagship university, which, in turn, affects the socio-economic development of the region, supplies it with the necessary research developments and personnel.

In the Novgorod Region, there is a gradual trend towards an increase in the proportion of students studying on a full cost recovery basis: from $48.4 \%$ in 2010 to $54.7 \%$ in 2020 . The income of the university from various sources is growing (by 2.2 times over the past 10 years), as well as the scientometric indicators of the teaching staff (by 20-30\% since 2018). Unfortunately, the indicators of regional development cannot demonstrate such a positive trend.

At present, the Russian regions, and, consequently, the regional universities, are facing new goals and objectives. The first stage of the inclusion of Russian universities has been completed, and it has had its effect in the development of science. Now the second stage has begun: it is necessary to move from quantity to quality. NovSU, actively developing and 
restructuring all areas of its activities (educational and research ones in the first place) in the direction of innovation and technological development, has already proved with the first results that it is developing in the right direction. The development of the university, of course, is in close relationship with the economic development of the region. The results of our study show that over the three years of transformation, the first positive trends have already been achieved in the development of the university's research potential and its impact on the region's economy (the development of economically promising scientific and industrial collaborations).

One of the important trends for the transition from a quantitative to a qualitative result is a decrease in the share of conference articles in the total number of university scientific articles. After analyzing the results of publication activity of NovSU, we are convinced that in a short period of time the university has successfully increased its performance (almost 3 times in 5 years) and is rapidly moving to a new level of development. The potential is quite large: if the course towards an increase in high-quality and, subsequently, highly cited articles is maintained, this will lead to an interdependent and synchronous increase in the development indicators of the university and the region, and the implementation of key regional projects and programs. This, of course, will have a positive impact on the formation and maintenance of the image of the Novgorod Region as a leading region in the field of high technologies (in medicine, agro-industrial complex, energy, industry), cultural, social, urban and anthropological studies.

\section{AUTHORS' CONTRIBUTIONS}

The authors made an equal contribution to the study: collection and analysis of material; definition of goals and objectives, research methods; formulation and scientific substantiation of conclusions, registration of key research results in the form of an article.

\section{REFERENCES}

[1] T.A. Klyachko, E.A. Semionova, "Contribution of Education to the Socio-Economic Development of the Subjects of the Russian Federation", Economy of Region, 2018, vol. 14(3), pp. 791-805. (In Russ.). DOI: $10.17059 / 2018-3-8$

[2] M.A. Katkova, Yu.S. Titova, "Digital economy: content and development trends", Izvestiya of
Saratov University. Economics. Management. Law, 2019, vol. 19(3), pp. 257-264. (In Russ.). DOI: 10.18500/1994-2540-2019-19-3-257-264

[3] Yu.Ya. Dranev, I.I. Kuchin, M.A. Fadeev, "The contribution of digitalization to the growth of the Russian economy" [Vklad tsifrovizatsii $\mathrm{v}$ rost rossiyskoy ekonomiki], Digital Economy: Express Information, 2018, vol. 8(91), pp. 1-2. (In Russ.).

[4] I.B. Yulenkova, "Factors in Innovative Development of a Region”, Russian Journal of Regional Studies, 2019, vol. 27(4-109), pp. 661-677. (In Russ.). DOI: 10.15507/24131407.109.027.201904.661-677

[5] A.I. Baranovsky, V.G. Volvach, "Education is the main resource of social and economic development of regions and formation of the middle class", Bulletin of the Altai Academy of Economics and Law [Vestnik Altayskoy akademii ekonomiki i prava], 2019, vol. 10(1), pp. 10-15. (In Russ.). DOI: 10.17513/vaael.739

[6] O.S. Gaponova, S.V. Smeltsova, Yu.Yu. Chilipenok, "Integration of Higher Education Institutions to Address the Challenges of Regional Socio-Economic Development", Economy of Region, 2020, vol. 16(4), pp. 11471161. (In Russ.). DOI: 10.17059/ekon.reg.20204-10

[7] P.S. Avetisyan, N.M. Gevorgyan, "Free Educational Environment as the Basis of Human Capital and Relationships between Social Sectors", Economy of Region, 2020, vol. 16(2), pp. 494-506. (In Russ.). DOI: $10.17059 / 2020-2-12$

[8] O.A. Donskikh, "University is Making Networks", Higher Education in Russia, 2018, vol. 27(10), pp. 164-167. (In Russ.). DOI: 10.31992/0869-3617-2018-27-10-164-16

[9] O.P. Ivanova, Yu.V. Daneykin, V.A. Trifonov, A.V. Mukhacheva, S.I. Chopozov, "Influence of the regional socio-economic system on the development of the university", Economy. Computer Science, 2021, vol. 48(2), pp. 217228. (In Russ.). DOI: 10.52575/2687-09322021-48-2-217-228

[10] G.E. Mekush, A.V. Antonova, Y.A. Zheleznov, "Assessment of database of multispectral shooting for environmental and economical checking of disturbed lands", In Proceeding of IOP Conference Series: Earth and Environmental Science, 2021, vol. 666(6), 
p. 062074. DOI: $\quad$ 10.1088/17551315/666/6/062074

[11] O.V. Leshukov, D.G. Yevseeva, A.D. Gromov, D.P. Platonova, “Assessment of the contribution of regional higher education systems to the socio-economic development of Russian regions", Modern Analytics of Education, 2017, vol. 3(11), 30 p. (In Russ.).

[12] O.P. Ivanova, V.A. Trifonov, Yu.V. Daneykin, "Assessment of the University's Contribution to Regional Development", Advances in Economics, Business and Management Research (AEBMR): In Proceedings of ISPC "Russia 2020 - a new reality: economy and society", Veliky Novgorod: Atlantis Press, 2021, pp. 188-192. DOI: 10.2991/aebmr.k.210222.037

[13] Yu.I. Pysheva, E.V. Zander, A.I. Pyzhev, "Toward the sustainable development of
Russian regions: a comprehensive review of empirical research", Journal of Siberian Federal University. Humanities \& Social Sciences, 2021, vol. 14(7), pp. 1063-1079. (In Russ.). DOI: $10.17516 / 1997-1370-0785$

[14]E.V. Popov, W. Strielkowski, M.V. Vlasov, "Digitalization of intellectual activity in Russian regions", The Manager, 2020, vol. 11(1), pp. 24-32. DOI: $10.29141 / 2218-5003-2020-11-$ 1-3

[15] Regional law of the Novgorod Region dated April 4, 2019 No. 394-OZ “On Strategy for Socio-economic Development of the Novgorod Region until 2026" [Oblastnoj zakon Novgorodskoj oblasti ot 04.04.2019 № 394-OZ "O Strategii social'no-ekonomicheskogo razvitiya Novgorodskoj oblasti do 2026 goda] (In Russ.). Retrieved from https://ipbd.ru/doc/5300201904040005/ 